\title{
Determination of Oil Change Interval for Diesel Engines According to the Quantity of Non- Ferrous Metals
}

\author{
Vladimír Hönig \\ Faculty of Agrobiology, Food and Natural Resources, Department of Chemistry, Czech University of Life Sciences Pra- \\ gue, Kamýcká 129, 165 21, Prague 6 - Suchdol, Czech Republic \\ E-mail: honig@af.czu.cz
}

\begin{abstract}
The article deals with the determination of the life of the lubricant based on the determination of the degree of wear or deterioration of the engine oil by wear particles. Non-ferrous particulates of a large diesel engine and their determination based on laboratory tribotechnical diagnostic tests are characteristic for the purposes of article. The combination of Atomic Absorption Spectrometry and Thin Layer Chromatography is used for measurements. The statistical method of discriminatory analysis is used to evaluate the article. The lifetime of the lubricant is thus determined according to objectively determined criteria realized by normalized and customized analyzes of the lubricant at a high degree of accuracy. The proposed and verified method demonstrates the degree of achievement of individual lubricant wear limits of non-ferrous metals in a large compression-ignition engine. The clear advantage of the proposed method is the precise determination of the optimal oil change interval and the possibility of early detection of a vehicle defect.
\end{abstract}

Keywords: Engine Oil, Wear Particles, Nomogram the Wear, Discriminant Analysis, Atomic Absorption Spectrometry

\section{Ackowledgement}

The article was edited under the financial support of project CIGA CULS Prague 20173001 - Utilization of butanol in compression ignition engines of generators.

\section{References}

[1] HÖNIG, V., HROMÁDKO, J. (2014). Possibilities of using vegetable oil to power diesel engines as well as their impact on engine oil, Agronomy Research Vol. 12, No. 8, pp. 323 - 332. Estonian Agricultural University. Estonia.

[2] ALEŠ, Z., PEXA, M., PAVLŮ, J. (2012). Tribotechnical diagnostics of agricultural machines, Engineering for Rural Development conference Jelgava, 24.-25.05.2012, [online]. [cit.2014-05.01] Available at www: http://www. http://tf.llu.lv.

[3] MIHALČOVÁ, J., HEKMAT, H. (2008).Tribotechnická diagnostika v prevádzke použitých olejov I. metódy hodnotenia častíc opotrebovania v olejoch, Chemické listy Vol. 102, pp. 358 - 362. Czech Society of Chemical Engineering, Prague, Czech Republic.

[4] PEXA, M., ALEŠ, Z., PAVLŮ, J., ČEDÍK, J. (2015). Analysis of Wear Particles Morphology of Machine Parts Based on Aluminium. Manufacturing Technology, Vol. 15, No. 4, pp. 664 - 670, J. E. Purkyne University in Ústí nad Labem nad Labem. Czech Republic.

[5] ALEŠ, Z., PAVLŮ. J., SVOBODOVÁ, J., PEXA, M. (2016). Use of Microscopy for Morphology Analysis of Wear Particles Generated in the Fuel Systems of Internal Combustion Engine, Manufacturing Technology, Vol. 16, No. 5, pp. 849-853, J. E. Purkyne University in Ústí nad Labem nad Labem. Czech Republic.

[6] BAKAlOVA, T., PETKOV, N., BAHCHEDZHIEV, H., KEJZLAR, P., LOUDA, P. (2016). Comparision of Mechanical and Tribological Properties of TiCN and CrCN Coatings Deposited by CAD, Manufacturing Technology, Vol. 16, No. 5, pp. 854-858, J. E. Purkyne University in Ústí nad Labem nad Labem. Czech Republic.

[7] HÖNIG, V., ORSÁK, M. (2016). Wear of Engine Oils Using Gaseous Fuels, Manufacturing Technology, Vol. 16, No. 5, pp. 923-927, J. E. Purkyne University in Ústí nad Labem nad Labem. Czech Republic.

[8] HÖNIG, V., MIHOLOVÁ, D., ORSÁK, M. (2014). Measurement of Wear Metals in Engine Oils by Atomic Absorption Spektrometry Method. Manufacturing Technology, Vol. 14, No. 3, PP. 317 - 322, J. E. Purkyne University in Ústí nad Labem nad Labem. Czech Republic.

[9] HÖNIG, V., SMRČKA, L., HORNÍČKOVÁ, Š. (2014). Application of discriminant analysis in monitoring the wear particles in the engine oil. Manufacturing Technology, Vol. 14, No. 3, pp. 322 - 326, J. E. Purkyne University in Ústí nad Labem nad Labem. Czech Republic. 
[10] PAVLŮ, J., HÖNIG, V., ALEŠ, Z., CHOTĚBORSKÝ, R. (2016). Tribodiagnostic Analysis of Motor oil after Failure of Turbocharger of Combustion Engine, Manufacturing Technology, Vol. 16, No. 5, pp. 1115-1122, J. E. Purkyne University in Ústí nad Labem nad Labem. Czech Republic.

[11] HÖNIG, V. (2015). Morphological Classification of Nonferrous Wear Particles in Engine Oil Using Pherrographical Method. Manufacturing Technology, Vol. 15, No. 4, pp. 530 - 534, J. E. Purkyne University in Ústí nad Labem nad Labem. Czech Republic.

\section{Paper number: M2017167}

Copyright $\odot$ 2017. Published by Manufacturing Technology. All rights reserved. 